\title{
White Cabbage Extract Reduces the Harmful Effects of Amiodarone on Heart Tissue in Rats
}

\author{
Beyaz Lahana Ekstresi Amiodaronun Sıçanlarda Kalp Dokusu Üzerindeki \\ Zararlı Etkilerini lyileştirir
}

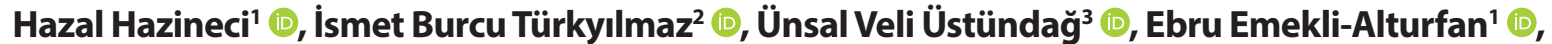

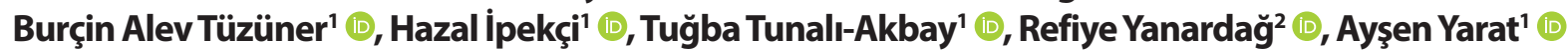

\author{
'Department of Basic Medical Sciences, Biochemistry, Faculty of Dentistry, Marmara University, İstanbul, Turkey \\ ${ }^{2}$ Department of Chemistry, Faculty of Engineering, Istanbul University-Cerrahpasa, Istanbul, Turkey \\ ${ }^{3}$ Department of Medical Biochemistry, Faculty of Medicine, Istanbul Medipol University, Istanbul, Turkey
}

ORCID ID: H.H. 0000-0002-5178-4568; I.B.T. 0000-0003-2789-5943; Ü.V.Ü. 0000-0003-0804-1475; E.E.A. 0000-0003-2419-8587; B.A.T. 0000-0001-5122-4977; H.I. 0000-0003-1193-168X; T.T.A. 0000-0002-2091-9298; R.Y. 0000-0003-4185-4363; A.Y. 0000-0002-8258-6118

Cite this article as: Hazineci H, Türkyılmaz IB, Üstündağ ÜV, Emekli-Alturfan E, Tüzüner BA, Ipekçi H, et al. White Cabbage Extract Reduces the Harmful Effects of Amiodarone on Heart Tissue in Rats. Experimed 2020; 10(1): 1-6.

\begin{abstract}
Objective: Amiodarone is used in the treatment of arrhythmia and has been shown to cause side effects in various organs. White cabbage (Brassica oleracea L. var. capitata) is a widely consumed vegetable. The effects of exposure to amiodarone and white cabbage consumption on heart tissue has not previously been investigated. We aimed to investigate the effects of white cabbage extract on amiodarone given to rats' cardiac tissues.
\end{abstract}

Material and Method: Rats were given white cabbage extract and amiodarone by gavage for seven days. Amiodarone was applied 1 hour after administration of the white cabbage extract. On the eighth day, the hearts of the animals were taken and homogenized. The levels of lipid peroxidation (LPO), reduced glutathione $(\mathrm{GSH})$, sialic acid (SA) and activities of glutathione-S-transferase (GST), catalase, superoxide dismutase (SOD) and tissue factor (TF) were determined.

Results: The GSH level, CAT and SOD activities decreased, while the LPO and SA levels increased in the amiodarone treated group. The White cabbage extract prevented any damage of the amiodarone by decreasing the amount of LPO and SA and also strengthened the antioxidant defence system by increasing the amount of the GSH and SOD activities and the CAT and GST activities.

Conclusion: It is suggested that the consumption of white cabbage could be an alternative approach to the prevention of the adverse effects of amiodarone on heart tissue.

Keywords: Amiodarone, side effect, white cabbage
ÖZ

Amaç: Aritmi tedavisinde kullanılan amiodaronun çeşitli organlarda yan etkilere neden olduğu gösterilmiştir. Beyaz lahana (Brassica oleracea L. var. capitata) yaygın olarak tüketilen bir sebzedir. Amiodaron maruziyeti ve beyaz lahana tüketiminin kalp dokusu üzerindeki etkileri araştırılmamıştır. Beyaz lahana ekstraktının amiodaron uygulanan sıçanların kalp dokuları üzerindeki etkilerini araştırmayı amaçladık.

Gereç ve Yöntem: Sıçanlara yedi gün boyunca gavajla beyaz lahana ekstresi ve amiodaron verildi. Beyaz lahana ekstresinin uygulanmasından 1 saat sonra amiodaron uygulandı. Sekizinci günde, hayvanların kalpleri alındı ve homojenize edildi. Lipit peroksidasyon (LPO), indirgenmiş glutatyon (GSH), siyalik asit (SA) düzeyleri ile glutatyon-S-transferaz (GST), katalaz, süperoksit dismutaz (SOD) ve doku faktörü (TF) aktiviteleri belirlendi.

Bulgular: Amiodaron verilen grupta GSH, CAT, SOD aktiviteleri azalırken LPO ve SA seviyeleri arttı. Beyaz lahana, LPO ve SA miktarını azaltarak amiodaron zararını önledi. Ayrıca GSH düzeyleri ile SOD, CAT ve GST aktivitelerini artırarak antioksidan savunma sistemini güçlendirdi.

Sonuç: Beyaz lahana tüketiminin, amiodaronun kalp dokusunda olumsuz etkilerini önlemek için alternatif bir yaklaşım olabileceği ileri sürülebilir.

Anahtar Kelimeler: Amiodaron, yan etki, beyaz lahana 


\section{INTRODUCTION}

Amiodarone blocks the potassium channels that in turn inhibit the cardiac repolarization and the effective refractory period as a class III antiarrhythmic drug (1). Other actions of amiodarone include the blockades of the $\mathrm{Na}^{+}$, the non-competitive ss-adrenergic, $\mathrm{Ca}^{+2}$ channels and the reserpine-like sympatholytic effect. Amiodarone is widely used for the treatment of arrhythmias because of these actions $(1,2)$.

On the other hand, amiodarone has a very similar structure to the thyroid hormones as it is a benzofuran compound containing approximately $37 \%$ iodine by weight $(3,4)$. Accordingly it has been suggested that the ingestion of $200 \mathrm{mg}$ of amiodarone as a standard daily dosage leads to $75 \mathrm{mg}$ of organic iodine ingestion each day and the subsequent deiodination via drug metabolism results in the release of nearly $6 \mathrm{mg}$ of iodine circulating freely, which is much more than the daily iodine intake (4-6). Moreover, owing to its high lipid affinity, amiodarone is commonly found in the tissues of the liver, lungs, skin, eyes, adipose tissue, muscle (especially myocardium) and the thyroid gland that explains its side effects in different organs (4).

Epidemiological data and in vitro studies propose that vegetables with antioxidant phytochemicals possess beneficial effects against some degenerative diseases like cancer and cardiovascular diseases. Belonging to the family Cruciferae, cabbage (Brassica oleracea L. var. capitata) is an important vegetable grown nearly all over the World. Cabbage is cultivated for its large leafy head and various cabbage types of differing shapes, sizes and colours exist (7). Cultivated cabbages can be found in different forms and are categorised as white, red and savoy cabbage $(7,8)$. Cabbage has been used for medicinal purposes for different types of diseases as well (9).

Excessive reactive oxygen species (ROS) formation may directly harm macromolecules including DNA, protein and lipids and may change several signal pathways by the induction of ROS sensitive transcription factors. Accordingly antioxidant molecules are needed for the detoxification of these ROS (10). There is a debate in literature about the oxidant potential of amiodarone. Some studies suggest that amiodarone is able to inhibit lipid peroxidation, acting as an antioxidant molecule whereas others report its oxidant effect (11). It has been suggested being used as a hepatic mitochondrial uncoupling oxidative phosphorylation, to inhibit the enzymes of electron transport chain and to impair $\beta$-oxidation of fatty acids (12-14). Mitochondrial $\beta$-oxidation and oxidative phosphorylation are the major physiological processes since the disruption of these pathways affect the function of many organs (12). The heart is a vital organ with a high-energy demand that is rich in mitochondria. It has been estimated to occupy approximately one third of the cardiac myocyte volume and each adult ventricular myocyte contains several thousand mitochondria (15). Therefore the heart is especially vulnerable to mitochondrial oxidative damage. Accordingly, the aim of this study was to evaluate the effects of white cabbage on the oxidant-antioxidant potential and tissue factor activities of amiodarone induced toxicity in rats' cardiac tissues for the first time in literature.

\section{MATERIAL AND METHOD}

\section{Preparation of the aqueous extract of white cabbage}

The leaves of white cabbages were gathered from Istanbul-Turkey. They were washed using distilled water and then the leaves were dried at room temperature. The dried leaves were extracted by adding distilled water and then they were boiled for 8 hours. After boiling, the extract was filtered and then lyophilised. Finally the extract was dissolved in distilled water and was given to the rats by gavage for seven days.

\section{Animals and experimental procedure}

In our study, 8-12 week old female Spraque Dawley type rats (300-350 g) obtained from the Marmara University Faculty of Medicine Animal Laboratory were used. All the experimental procedures were approved by the Institutional Animal Care and Use Committee of Marmara University (26.11.2014Mar). The experimental animals were divided into 4 groups, 5 in each. The rats were administered white cabbage extract $(500 \mathrm{mg} / \mathrm{kg}$ ) and amiodarone for seven days by gavage. During the experiment, amiodarone (100 mg/kg Amiodarone, Sigma, Saint Louis, USA) was administered 1 hour after the cabbage extract was given. At the end of the 7th day, all animals were fasted overnight and at the end of the 8th day they were then put down under ether anesthesia. The heart tissue samples of the rats were homogenized using saline solution $(0.9 \% \mathrm{NaCl})$. In $10 \%$ of the homogenates that were prepared from the heart tissues, the homogenates total protein levels were determined. To assess the oxidant-antioxidant status the levels of glutathione (GSH), lipid peroxidation (LPO), sialic acid (SA) and the activities of superoxide dismutase (SOD), catalase (CAT), glutathione-S-transferase (GST) and tissue factor (TF) were evaluated.

\section{Biochemical analysis}

Lowry's method was applied in order to measure the levels of total proteins. In this method, alkali medium proteins first react with copper ions and are then reduced by Folin reagent. At $500 \mathrm{~nm}$ the absorbance was determined. The calculated total protein levels were used to present the results per protein (16).

Malondialdehyde (MDA) is a product of LPO in tissues, and is evaluated in terms of the thiobarbituric acid reactive substances by Yagi's method (17). The LPO was expressed as nmol MDA/ mg protein in terms of the MDA equivalents.

The levels of GSH were measured in tissue homogenates using Beutler's method (18) by using extinction coefficient as $1.36 \mathrm{x}$ $10^{4} \mathrm{M}^{-1} \mathrm{~cm}^{-1}$ in the calculations. The results obtained were presented as $\mathrm{mg} \mathrm{GSH} / \mathrm{mg}$ protein.

CAT activities were evaluated using the method of Aebi (19) which is based on the transformation of hydrogen peroxide $\left(\mathrm{H}_{2} \mathrm{O}_{2}\right)$ into water through the effect of CAT enzyme. The transformation was noted by the decrease in the absorbances obtained at $240 \mathrm{~nm}$ and the activity of CAT were presented as $\mathrm{U} / \mathrm{mg}$ protein. 
SOD activities were determined by riboflavin-sensitized photooxidation of ortho-dianisidine (20). Ortho-dianisidine oxidation, by the reaction with riboflavin is induced by SOD. The increase in absorbance depends on the SOD concentration. Finally, the coloured product's absorbance is determined using spectrophotometry at $460 \mathrm{~nm}$.

The activity of GST in the samples was evaluated at $340 \mathrm{~nm}$ by the spectrophotometer and the results were presented as $\mathrm{U} /$ mg protein (21).

The levels of SA were evaluated using the method of Warren (22). For the assay, the homogenates were first incubated at $80^{\circ} \mathrm{C}$ for 1 hour with $0.1 \mathrm{NH}_{2} \mathrm{SO}_{4}$ and the hydrolysate was used for analysis. The absorbances obtained from the samples were determined at $549 \mathrm{~nm}$ and the results were presented as the mg SA/ mg protein.

The method of Quick was used to measure the TF activities of homogenates by Quick's one-stage method. For the assay, pooled plasma was obtained from from healthy subjects. Since the clotting time is inversely proportional to the activity of TF, the lengthening of the clotting time shows decreased TF activity (23).

\section{Statistical Analysis}

Statistical analysis was applied by using GraphPad Prism version 6 (GraphPad Software, San Diego, USA). All the results obtained were presented as a means and standard deviation. The data groups were compared using Kruskal-Wallis and Mann-Whitney $U$ tests. The values of $p<0.05$ were accepted as significant.

\section{RESULTS}

The LPO levels in terms of MDA in heart tissues of the four groups are given in Figure 1. The MDA levels of the amiodarone group were found to be higher when compared to the control group $(p<0.05)$. The MDA levels decreased significantly

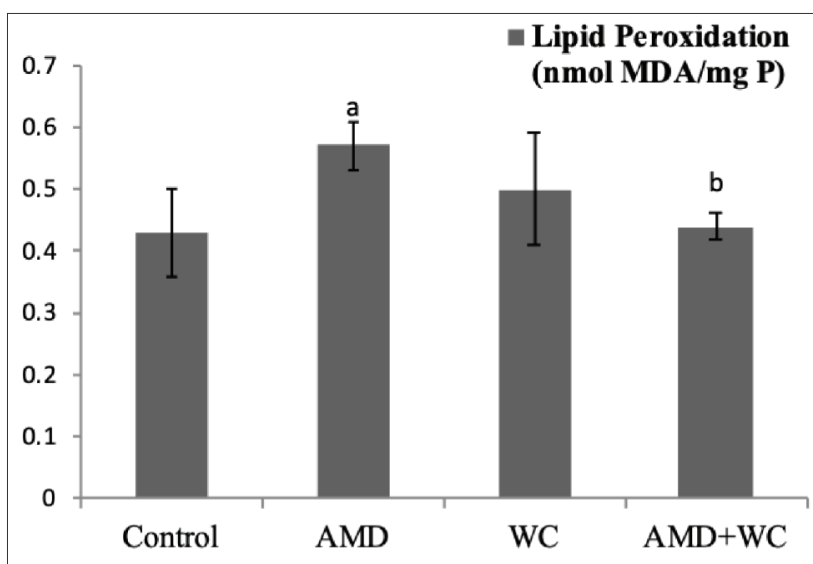

Figure 1. Lipid peroxidation levels of the Control; AMD; WC and AMD+WC groups. ${ }^{\mathrm{a}} \mathrm{p}<0.05$, significantly different compared to the Control group; ${ }^{b} p<0.05$ significantly different compared to the AMD group. AMD: Amiodarone; WC: White cabbage. in the amiodarone+white cabbage group compared to the amiodarone group (Figure 1). The level of GSH decreased significantly when compared with the control group in the amiodarone and white cabbage groups. In the amiodarone+white cabbage group, the heart tissue GSH levels increased significantly compared to the amiodarone group (Figure 2).

When the groups were compared in terms of the catalase activities of the heart tissues, the catalase activity in the amiodarone group decreased significantly compared to the control group. In the amiodarone+white cabbage group, the catalase activity increased significantly compared to the amiodarone group (Figure 3). The SOD activity of the white cabbage and amiodaron-

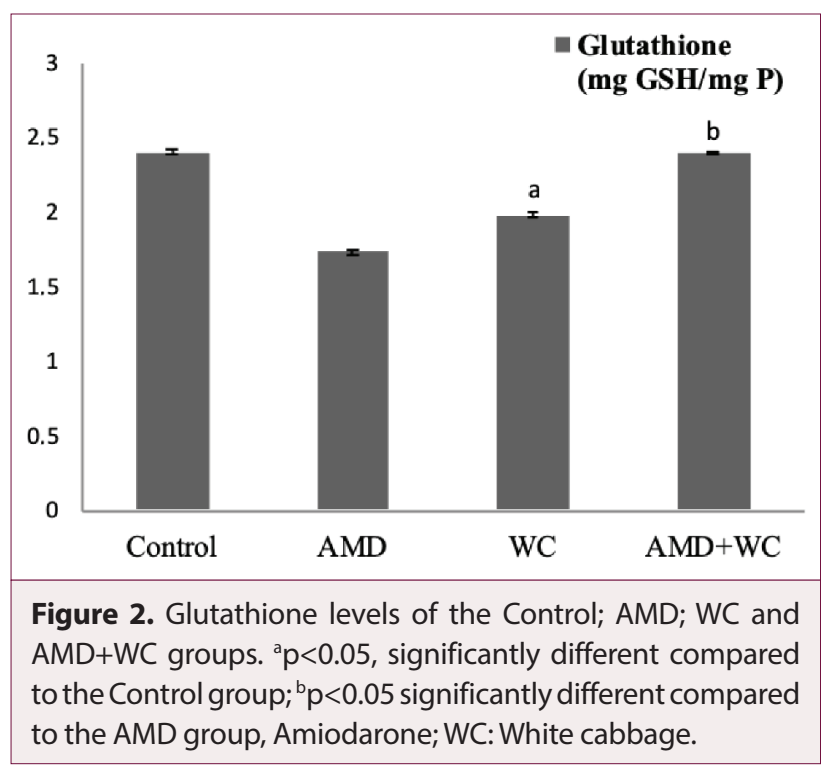

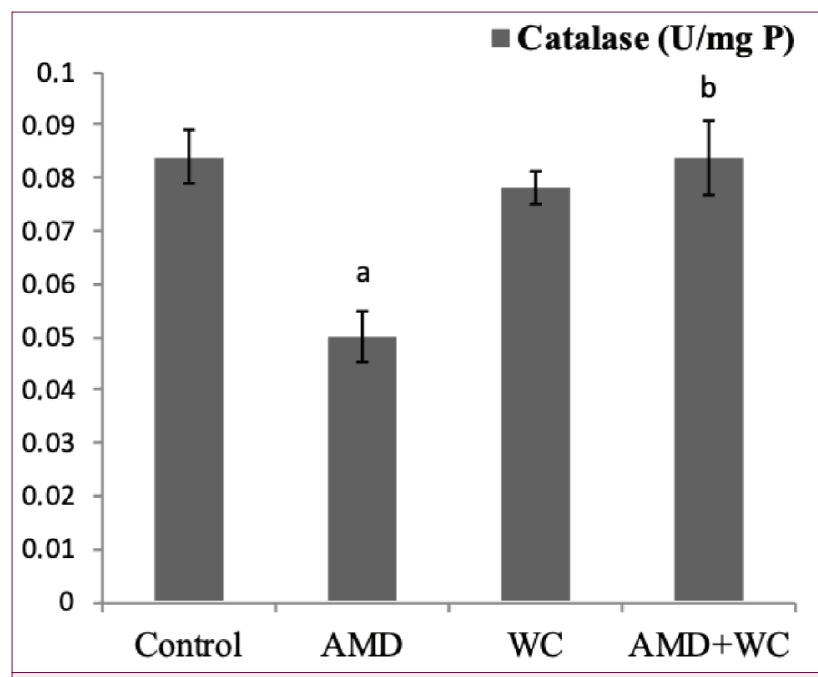

Figure 3. Catalase activities of the Control; AMD; WC and AMD+WC groups. ${ }^{a} \mathrm{p}<0.05$, significantly different compared to the Control group; ${ }^{b} \mathrm{p}<0.05$ significantly different compared to the AMD group; Amiodarone; WC: White cabbage. 


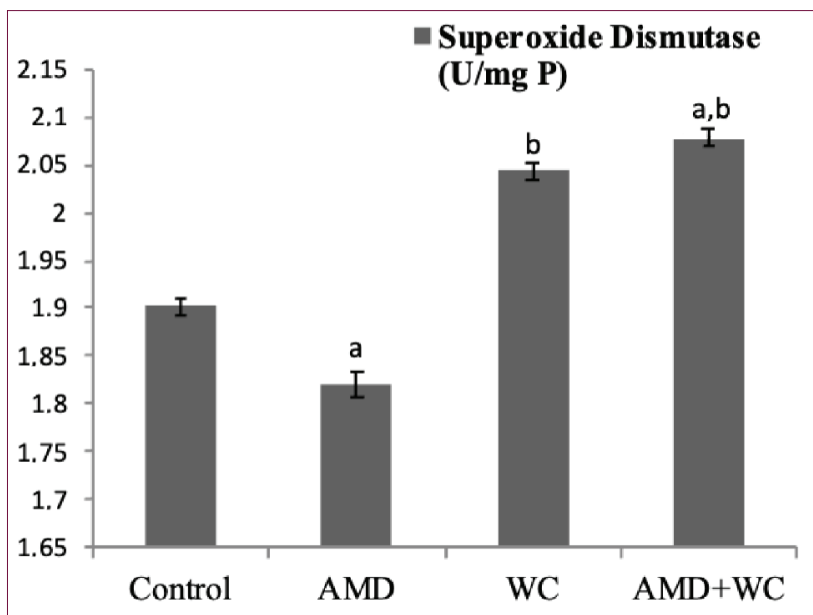

Figure 4. Superoxide dismutase activities of the Control; AMD; WC and AMD+WC groups. ${ }^{\mathrm{a}} \mathrm{p}<0.05$, significantly different compared to the Control group; ${ }^{b} p<0.05$ significantly different compared to the AMD group; Amiodarone; WC: White cabbage.

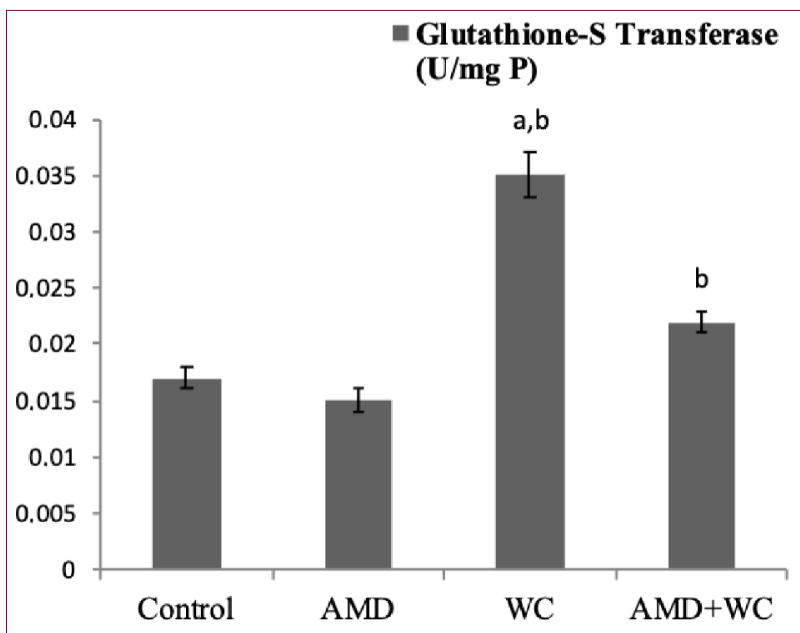

Figure 5. Glutathione-S-transferase activites of the Control; $A M D ; W C$ and $A M D+W C$ groups. ${ }^{a} p<0.05$, significantly different compared to the Control group; ${ }^{b} p<0.05$ significantly different compared to the AMD group, Amiodarone; WC: White cabbage.

e+white cabbage groups increased significantly when compared with the control group (Figure 4). The GST activity of the white cabbage and the amiodarone+white cabbage groups were found to be significantly higher compared to the white cabbage group. Also the GST activity of white cabbage group was significantly higher compared to the control group (Figure 5). The amount of SA in the amiodarone group increased significantly compared to the control group and white cabbage treatment decreased SA levels significantly in the amiodarone group ( $p<0.05$ ) (Figure 6). TF activity in amiodarone and white

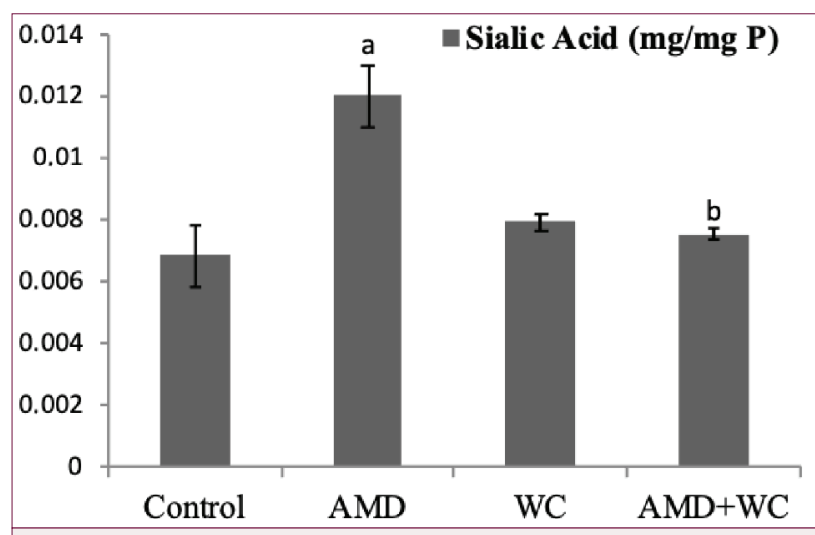

Figure 6. Sialic acid levels of the Control; AMD; WC and AMD+WC groups. ${ }^{a} \mathrm{p}<0.05$, significantly different compared to the Control group; ${ }^{b} \mathrm{p}<0.05$ significantly different compared to the AMD group, Amiodarone; WC: White cabbage.

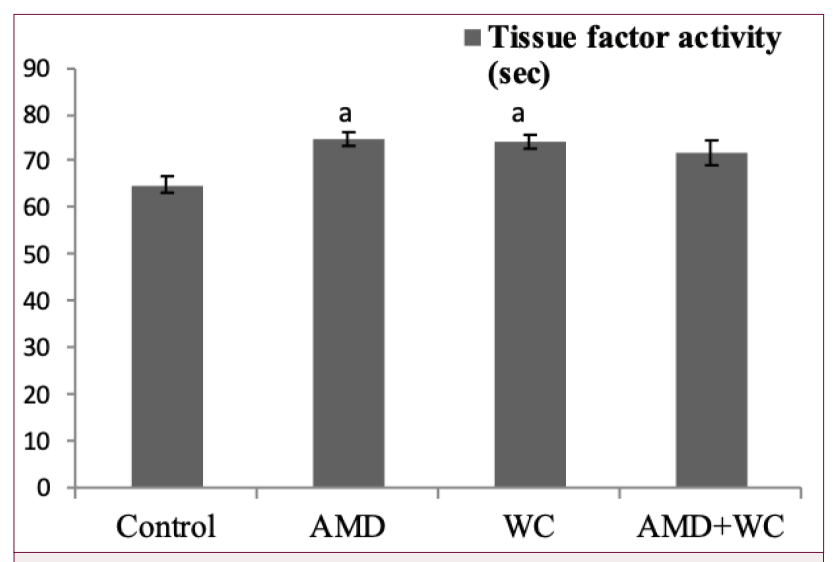

Figure 7. Tissue factor activities of the Control; AMD;WC and AMD+WC groups. ${ }^{a} p<0.05$, significantly different compared to the Control group, Amiodarone; WC: White cabbage.

cabbage groups was found to be significantly lower compared to the control group (Increase in seconds means a decrease in activity) (Figure 7).

\section{DISCUSSION}

According to the results of our study, white cabbage (Brassica oleracea L. var. capitata) has a positive effect against the toxicity caused by amiodarone on the heart tissues of rats. The toxic effect of amiodarone administration on rat heart tissue was manifested in the form of increased LPO and SA. In the amiodarone treated group, it was observed that the amount of GSH and activities of CAT and SOD decreased significantly. White cabbage prevented the damage of amiodarone by decreasing the amount of LPO and SA in the group given amiodarone, and also strengthened the antioxidant defence system by increasing the amount of GSH and the activities of SOD, CAT and GST. 
To date a lot of research has been conducted that focused on the beneficial phytochemicals present in cabbages, especially indole-3-carbinole (I3C). The indoles content and sulforaphane in cabbage induce antioxidant mechanisms and detoxification mechanisms that prevent cancer-inducing substances (24). Both epidemiological and in vitro studies strongly suggest that vegetables with phytochemicals having antioxidant effects may prevent different types of diseases (25). The beneficial effects of cruciferous vegetables have been shown to be related with their antioxidant phytochemicals, such as antioxidant vitamins like ascorbic acid, a-tocopherol and $\beta$-carotene (26). Carotenes, tocopherols and ascorbate are effective as antioxidants to prevent and to treat malignant diseases (27). Many studies have also reported that most of the antioxidant properites of vegetables can be due to their phenolic content like catechin, isocatechin, flavonoids, isoflavone, flavones and also anthocyanin (28).

Due to the interest in the role antioxidants in human health, new research focused on horticulture and food science to determine the antioxidant phytochemicals in different fruit and vegetables. Although carotene, tocopherol and ascorbic acid levels in the sub-species of $\mathrm{B}$. oleracea have been determined in some studies, the number of systematic research on the measurement of the antioxidant content in cabbage cultivars in different areas of the world are very limited $(27,28)$.

In our study, it was found that white cabbage increased the amount of GSH and the acitivities of CAT and SOD and decreased LPO in the amiodarone group. GSH is one of the key elements of the antioxidant defence system in the organism, it is involved in maintaining the normal structure and functions of cells with redox and detoxification reactions (26). Therefore, in our study, in the group given amiodarone, heart decreased GSH may induce the initiation of reactions due to free radicals.

The heart LPO level was found to be significantly higher in the amiodarone group compared to the control group. Disruption of the oxidant-antioxidant balance due to amiodarone has been shown previously. Chakraborty et al reported that amiodarone increased LPO in liver, kidney and testicular tissues of rats (28). LPO indicates oxidative damage of lipids in the cell membrane and is one of the side effects of amiodarone therapy (28).

In parallel with the increased LPO, amiodarone increased SA levels significantly when compared to the control group. Reactive oxygen species increase as a result of the decreased activity of antioxidant systems such as SOD, CAT and GSH. It has been reported that serum $\mathrm{SA}$ could be counted among the acute phase response elements and increased in some diseases such as myocardial infarction and diabetes (29). In inflammatory conditions, the amount of SA increases due to the increased concentrations of acute phase glycoproteins, whose sialization increases. Therefore, serum SA was stated be an inflammatory marker (29).

Amiodarone decreased TF activity in cardiac tissue compared to the control group. Breitenstein et al. evaluated the effects of amiodarone on thrombus formation and TF expression and reported that amiodarone inhibits thrombus formation in vivo (30). In our study, white cabbage decreased the activity of TF significantly. The positive effects of vegetarian nutrition on coagulation and vegetable consumption have been shown to decrease the incidence of acute coronary disease associated with thrombosis. Fibrinogen is accepted to be an independent thrombosis risk factor and it has been found that the level of fibrinogen decreases with white cabbage consumption $(30,31)$. There is also a strong correlation between lipids in blood and coagulation parameters. Change in lipids, coagulation protein, thrombocytes affects thrombosis through fibrinolytic factors. Accordingly it has been suggested that white cabbage may have an anticoagulant effect as a hypolipidemic vegetable (31).

\section{CONCLUSION}

Findings obtained from the results of our study show that in the case of amiodarone toxicity, white cabbage exerted its positive effects by improving the antioxidant system. The beneficial effects of white cabbage may be attributed to the high phenolic content of cabbage. Further studies that evaluate the molecular mechanisms of the effects related to the mitochondrial functions may be useful to reveal the details of these effects.

Ethics Committee Approval: All the experimental procedures were approved by the Institutional Animal Care and Use Committee of Marmara University (26.11.2014Mar).

Peer-review: Externally peer-reviewed.

Author Contributions: Concept - R.Y., E.E.A., A.Y.; Data Collection and/ or Processing - E.E.A.; Analysis and/or Interpretation - H.H., Ü.V.Ü., B.A.T., H.I.; Literature Search - H.I.., I.B.T.; Writing - H.H., E.E.A.; Critical Reviews - T.T.A., R.Y., A.Y.

Conflict of Interest: The authors have no conflict of interest to declare.

Financial Disclosure: This study was supported by the Marmara University Scientific Research and Project Commision (Project No: SAGCYLP-110315-0054).

Etik Komite Onayı: Tüm deneysel prosedürler Marmara Üniversitesi Kurumsal Hayvan Bakım ve Kullanım Komitesi (26.11.2014Mar) tarafından onaylanmıştır.

Hakem Değerlendirmesi: Dış bağımsız.

Yazar Katkıları: Fikir - R.Y., E.E.A., A.Y.; Veri Toplanması ve/veya İşlemesi - E.E.A.; Analiz ve/veya Yorum - H.H., Ü.V.Ü., B.A.T., H.I.; Literatür Taraması - H.I.., I.B.T.; Yazan - H.H., E.E.A.; Eleştirel İnceleme - T.T.A., R.Y., A.Y.

Çıkar Çatışması: Yazarlar çıkar çatışması bildirmemişlerdir.

Finansal Destek: Bu çalışma Marmara Üniversitesi Bilimsel Araştırma ve Proje Komisyonu, (Proje No: SAG-C-YLP-110315-0054) tarafından desteklenmiştir. 


\section{REFERENCES}

1. Oliveira PF, Dias da Silva VJ, Salgado MCO, Fazan Jr. R, Aguiar CA, Salgado HC. Acute effect of amiodarone on cardiovascular reflexes of normotensive and renal hypertensive rats. Braz J Med Biol Res 2005; 38(6): 967-76. [CrossRef]

2. Hughes $M$, Binning $A$. Intravenous amiodarone in intensive care. Intensive Care Med 2000; 26: 1730-39. [CrossRef]

3. Rao RH, McCready VR, Spathis GS. lodine kinetic studies during amiodarone treatment. J Clin Endocrinol Metab 1986; 62: 563-8. [CrossRef]

4. Narayana SK, Woods DR, Boos CJ. Management of amiodarone-related thyroid problems. TAEM 2011; 2(3): 115-26. [CrossRef]

5. Basaria S, Cooper DS. Amiodarone and the thyroid. Am J Med 2005; 118(7): 706-14. [CrossRef]

6. Bogazzi F, Bartalena L, Gasperi M, Braverman LE, Martino E. The various effects of amiodarone on thyroid function. Thyroid 2001; 11(5):511-9. [CrossRef]

7. Singh J, Upadhyay AK, Bahadur A, Singh B, Singh KP, Rai M. Antioxidant phytochemicals in cabbage (Brassica oleracea L. var. capitata) Sci Hortic 2006; 108(3): 233-37. [CrossRef]

8. Nieuwhof M. Cole Crops: Botany, Cultivation and Utilization. World Crops Series. Leonard Hill, London, UK, 1969; pp353.

9. DeFilipps RA, Krupnick GA. The medicinal plants of Myanmar. PhytoKeys 2018; 28;(102): 1-341. [CrossRef]

10. Wells PG, McCallum GP, Chen CS, Henderson JT, Lee CJ, Perstin J, et al. Oxidative stress in developmental origins of disease: teratogenesis, neurodevelopmental deficits, and cancer. Toxicol Sci 2009;108: 4-18. [CrossRef]

11. Lapenna D, Ciofani G, Bruno C, Pierdomenico SD, Cuccurullo F. Antioxidant activity of amiodarone on human lipoprotein oxidation. BJP 2001; 133(5): 739-45. [CrossRef]

12. Felser A, Blum K, Lindinger PW, Bouitbir J, Krähenbüh S. Mechanisms of hepatocellular toxicity associated with dronedarone--A comparison to amiodarone. Toxicol Sci 2013; 131(2): 480-90. [CrossRef]

13. Lewis JH, Ranard RC, Caruso A, Jackson LK, Mullick F, Ishak KG, et al. Amiodarone hepatotoxicity: Prevalence and clinicopathologic correlations among 104 patients. Hepatology 1989; 9: 679-85. [CrossRef]

14. Waldhauser KM, Török M, Ha HR, Thomet U, Konrad D, Brecht $K$, et al. Hepatocellular toxicity and pharmacological effect of amiodarone and amiodarone derivatives. J. Pharmacol Exp Ther 2006; 319: 1413-23. [CrossRef]

15. Brown DA, Perry JB, Allen ME, et al. Expert consensus document: Mitochondrial function as a therapeutic target in heart failure. Nat Rev Cardiol. 2017; 14(4): 238-50. [CrossRef]
16. Lowry OH, Rosebrough NJ, Farr AL, Randall RJ. Protein measurement with the Folin phenol reagent. J Biol Chem 1951; 193(1): 265-75.

17. Yagi K. Assay for blood plasma or serum. Methods Enzymol 1984; 105: 328-37. [CrossRef]

18. Beutler E. Gluthatione: red cell metabolism. A manual biochemical methods. New York: Grune and Stratton; 1975.

19. Aebi H. Catalase in vitro. In: Bergmeye HU, editor. Methods of enzymatic analysis. Wenheim: Verlag Chemie; 1974. [CrossRef]

20. Mylorie AA, Collins H, Umbles C, Kyle J. Erythrocyte SOD activity and other parameters of copper status in rats ingesting lead acetate. Toxicol Appl Pharmacol 1986; 82: 512-20. [CrossRef]

21. Habig WH, Jacoby WB. Assays for differentation of glutathione-Stransferases. Methods Enzymol 1981; 77: 398-405. [CrossRef]

22. Warren $\mathrm{L}$. The thiobarbituric acid assay of sialic acids. J Biol Chem 1959; 234: 1971-75.

23. Ingram GIC, Hills M. Reference method for the one stage prothrombin time test on human blood. Thromb Haemostas 1976; 36: 237-8. [CrossRef]

24. Brooks JD, Paton VG, Vidanes G. Potent induction of phase 2 enzymes in human prostate cells by sulforaphane. Cancer Epidemiol Biomarkers Prev 2001; 10(9): 949-54.

25. Dekker $M$, Verkerk R, Jongen WM. Predictive modelling of health aspects in the food production chain: a case study on glucosinolates in cabbage. Trends Food Sci 2000; 11: 174-81. [CrossRef]

26. Ji C, Li C, Gong W, Niu H, Huang W. Hypolipidemic action of hydroxycinnamic acids from cabbage (Brassica oleracea L. var. capitata) on hypercholesterolaemic rat in relation to its antioxidant activity. J Food Nutr Res 2015; 3(5): 317-24. [CrossRef]

27. Simin N, Orcic D, Cetojevic-Simin D, Mimica-Dukic N, Anackov G, Beara I, Bozin B. Phenolic profile, antioxidant, anti-inflammatory and cytotoxic activities of small yellow onion (Allium flavum $\mathrm{L}$. subsp. flavum, Alliaceae). LWT-Food Sci Technol 2013; 54(1): 13946. [CrossRef]

28. Chakraborty A, Mondal C, Sinha S, Mandal J, Chandra AK. Amiodarone induced oxidative stress in stress - vulnerable organs of adult male rats. Asian J Pharm Clin Res. 2014; 7: 4:177-83.

29. Ponnio M, Alho H, Nikkari ST, Olsson U, Ryderberg U, Sillanaukee P. Serum sialic acid in a random sample of the general population. Clin Chem 1999; 45: 1842-9. [CrossRef]

30. Breitenstein A, Stämpfli SF, Camici GG, Akhmedov A, Ha H, Follath $F$, et al. Amiodarone inhibits arterial thrombus formation and tissue factor translation. Arter Thromb Vasc Biol 2008;28: 2231-8. [CrossRef]

31. Khan R.A, Asad Ti, Feroz Z, Ahmed M. In vivo examinatıon of the anticoagulant effect of the Brassica oleracea methanol extract. Arch Biol Sci Belgrade 2015; 67(2), 631-8. [CrossRef] 